\title{
Chapter 25 \\ Impact of Replacing Conventional Cars with Electric Vehicles on UK Electricity Grid and Carbon Emissions
}

\author{
George Milev, Amin Al-Habaibeh, and Daniel Shin
}

\begin{abstract}
This paper estimated the effect of electric vehicle transition on UK road and how it impacts on electricity supply and the reduction of carbon emissions. It used a scenario in which all cars that utilise internal combustion engines will be replaced by EVs in the UK. The methodology is based on speculating the future number of EVs in Great Britain, which helped in estimating the amount of additional electricity usage that would be required for the scenario. The results revealed that approximately $81 \mathrm{TWh}$ of additional electricity must be produced annually to compensate for such expansion of EV. With that increase in electricity generation, the levels of carbon emissions from the electrical grid will rise slightly, by about 8.6 million tonnes of carbon dioxide per year. Given that combustion vehicles contribute to about $42 \%$ of the carbon emissions from the transport sector in the UK, it is concluded that the total amount of $\mathrm{CO}_{2}$ in the country will decrease by approximately $12 \%$ of all cars with internal combustion engines are replaced by electric vehicles.
\end{abstract}

Keywords Electric $\cdot$ Car $\cdot$ Environment $\cdot$ Carbon $\cdot$ Emission

\subsection{Introduction}

Over the past few decades, the technology around transportation has evolved and shown dramatic developments. With the UK government pushing to go carbon neutral by 2050 [1], the demand for Electric Vehicle (EV) has had a huge rise more recently. This may due to the tendency of government legislation beginning to restrict the use of combustion vehicles (CV) on the road in order to further reduce Carbon Emission $\left(\mathrm{CO}_{2}\right)$. However, electricity is an energy source for $\mathrm{EV}$ which also produces $\mathrm{CO}_{2}$ but much less than burning combustion engines. Hence, it is crucial to estimate the $\mathrm{CO}_{2}$ reduction resulting from increasing the transition to $\mathrm{EV}$. This study, therefore, analysed the reduction of $\mathrm{CO}_{2}$ levels by comparing the current electricity usage in the UK against the scenario of UK road making $100 \%$ EV transition.

G. Milev $(\bowtie) \cdot$ A. Al-Habaibeh · D. Shin

Department of Product Design, Nottingham Trent University, Nottingham, UK

e-mail: george.milev@ntu.ac.uk 


\subsubsection{Description of $C V$ and $E V$}

The first modern petrol internal combustion engine (ICE) was constructed in the 1880s [2]. The difference between electric and ICE vehicle is that conventional cars burn fuel in the ICE, whereas EV store energy into a battery, which powers an electric motor [3]. However, assembling the combustion vehicle (CV) was a complex process. Therefore, at the end of the 19th century, EV was more favoured by people, for example, $90 \%$ of taxicabs were electric in 1899's New York [4].

In $\mathrm{CV}$, the mixture of fuel and air is ignited by the sparks, causing a small explosion, resulting in downward movements of the engine's pistons. One of the by-products of the burnt fuel is carbon dioxide, which is released in the atmosphere during this process. It has been estimated that on average, a CV emits about 122 carbon dioxide per kilometre [5]. For EV, the electric energy is stored in the battery of the car and it provides power to the car's controller. The controller transfers that energy to the electric motor, which generates horsepower to spin the wheel [3]. Some models have a motor that is installed on each axle [6]. In research studying the performance of both $\mathrm{CV}$ and EV, it was found that EVs are 3.6 times more efficient in energy consumption [7]. EV use 3.4 times less total energy while driven compared to ICE vehicles, and also that combustion-powered cars emit 4.5 times more carbon emissions while in use [7].

\subsubsection{EV Market Size}

According to the latest reports of the UK's Department for Transport, there were a total of 38.9 million vehicles in the country, of which $82.43 \%$ (32 million) were cars and taxis [8]. Currently, in the UK there are more than 298,000 electric car models on the roads. Recent figures show that plug-in battery vehicles make up about $34 \%$ of the total new vehicle registrations in Great Britain [9]. When it comes to emissions popularity and energy/fuel consumption, the popularity of vehicles plays an important role.

Table 25.1 summarises the popularity of EV in the UK and their energy consumption. Tesla Model 3 and Nissan Leaf are the most popular electric vehicles in the country. Annually, all cars are traveling about 415 billion kilometres, or approximately $12,968.75 \mathrm{~km}$ on average [8].

\subsubsection{Electricity Demand and Carbon Emissions in the UK}

For the last 6 years, the electricity consumption rate in the UK has been dropping, particularly for households due to milder winters in recent years [10]. According to UK government data, households consume approximately $105 \mathrm{TWh}$ of electricity 


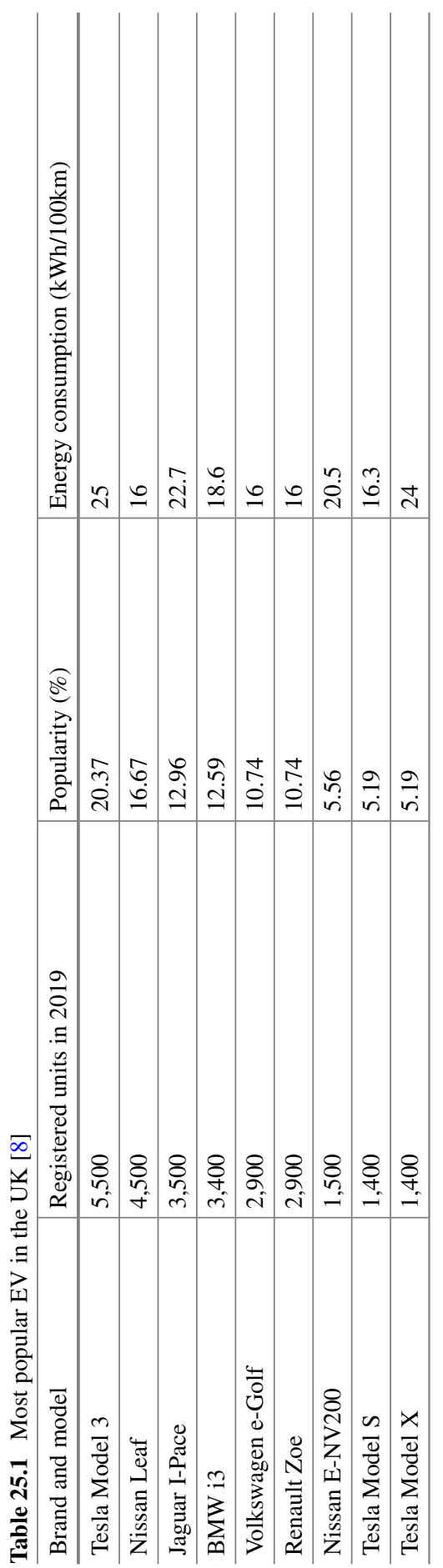


Fig. 25.1 Electricity generation mix in the UK [12]

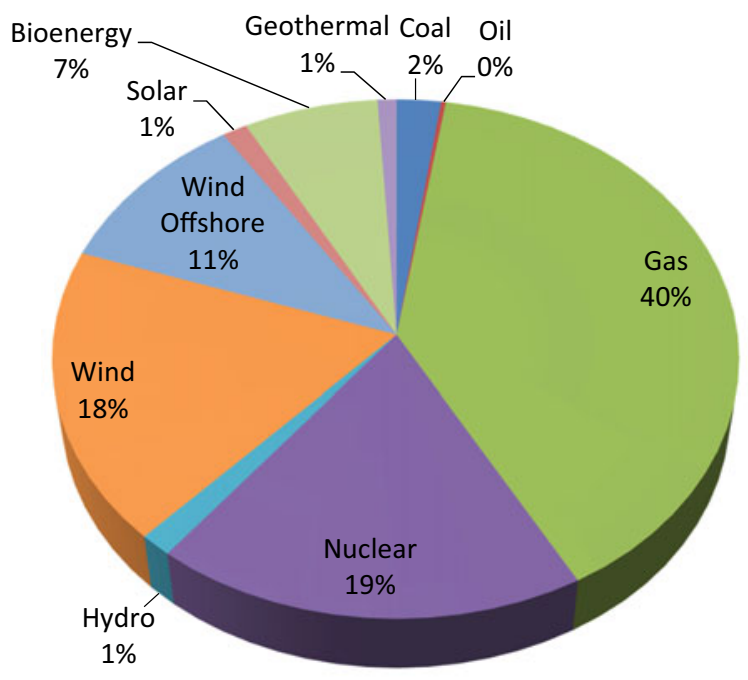

per year, which is reduced from 115 TWh since 2012 [10]. In energy supply, it was measured that the annual electricity production was $307 \mathrm{TWh}$ in 2019 , which is reduced from 325.17 TWh in 2012 [11]. In recent years, the UK's energy generation mix has reduced the use of coal and increased the usage of more renewable resources (Fig. 25.1).

Coal and gas contribute to a high amount of $\mathrm{CO}_{2}$ in the UK. However, $\mathrm{CO}_{2}$ level has been reducing for the last 5 years due to the reduction of using these energy sources and by increasing the use of renewable sources and nuclear power. The transport sector in Great Britain contributes to about 33\% of the carbon dioxide emissions $\left(119.6 \mathrm{MtCO}_{2}\right)$ in $2019,11 \%$ of reduction compared to $134.3 \mathrm{MtCO}_{2}$ in 2005 [14]. Power stations emit approximately $15 \%\left(57.4 \mathrm{MtCO}_{2} /\right.$ year) of the total carbon emissions [14]. It has been estimated that EV produces about $48 \mathrm{~g}$ of carbon emissions during the manufacturing stage, compared to $31 \mathrm{~g}$ for $\mathrm{CV}$, but in the longer-term, CV produce significantly more emissions from burning fuels [7].

\subsection{Methodology}

Through the literature review, the current study acquired the required parameters to estimate the amount of electricity needed in supply and how much of $\mathrm{CO}_{2}$ reduction can be generated for the scenario of electrifying all cars on UK road. In order to retrieve the proposed estimation, following 4 equations were set:

The study began by determining the average energy consumption (AEC) of EVs according to their brand and model popularity via using Eq. (25.1). 


$$
\sum_{i=1}^{n}=\left(E C_{i} \times P P_{i}\right)=\mathrm{AEC}
$$

EC represents the electricity consumption of each vehicle brand and model $(\mathrm{kWh} / 100 \mathrm{~km})$ and $\mathbf{P P}$ is the percentage proportion of electric cars according to their popularity, it is represented as (value)\%/100; $\mathbf{n}$ is the number of electric car brands and models included in our study that is 9 (Table 25.1).

The next stage was to calculate the total electricity needed based on the EV transition scenario, using Eq. 25.2:

$$
E R=(A T D \div 100) \times A E C
$$

ER represents the energy required based on the EV transition scenario in kWh, later converted to TWh; ATD is the annual traveling distance for all cars in the UK $(\mathrm{km})$; AEC is the average energy consumption of EV $(\mathrm{kWh} / 100 \mathrm{~km})$. The calculation also considered that there are about $7 \%(\mathbf{E R}+7 \%)$ distribution losses through the electricity grid in the UK [15] (Table 25.2).

In measuring the carbon emission, the current study estimated the emissions from cars using the following Eq. 25.3:

$$
E m=A T D \times C I
$$

where: $\mathbf{E m}$ is the carbon emissions released by all cars in the UK (kg), later converted to million tonnes; ATD is the average traveling distance $(\mathrm{km})$; CI is the carbon intensity of the cars $\left(\mathrm{kgCO}_{2} / \mathrm{km}\right)$.

Since EV does not produce any emissions while driven, the value for $\mathbf{E m}$, which represents the amount of Carbon dioxide that all cars in the UK emit annually, was subtracted from current $\mathrm{CO} 2$ emission on the road today. Both current and newly estimated road $\mathrm{CO}_{2}$ levels were compared. The final step was to estimate the changes

Table 25.2 Carbon intensity of electricity's sources [13]

\begin{tabular}{l|l}
\hline Source & $\mathrm{gCO}_{2} / \mathrm{kWh}$ \\
\hline Coal CCS & 220 \\
\hline Oil & 314 \\
\hline Gas CCS & 200 \\
\hline Nuclear & 26 \\
\hline Hydro & 7 \\
\hline Wind & 15 \\
\hline Solar PV & 88 \\
\hline Bioenergy & 165 \\
\hline Geothermal & 15
\end{tabular}


of $\mathrm{CO}_{2}$ under the EV transition scenario. The $\mathbf{E R}$ value from Eq. 25.2 was distributed accordingly to the UK's energy generation mix (i.e. $40 \%$ for gas, $19 \%$ for nuclear, etc.) This is due to each source of electricity emits a different amount of carbon emissions per kWh of electricity produced. Equation 25.4 was used to calculate the increased $\mathrm{CO}_{2}$ from each source and then they were summed to find the total amount.:

$$
\mathrm{CO}_{2}=\mathrm{ES} \times \mathrm{CI}
$$

$\mathrm{CO}_{2}$ is carbon dioxide emissions $\left(\mathrm{kgCO}_{2}\right)$, later converted to $\mathrm{MtCO}_{2}$; $\mathbf{E S}$ is the electricity generated by each source $(\mathrm{kWh})$; $\mathbf{C I}$ is the carbon intensity of each corresponding source $\left(\mathrm{kgCO}_{2} / \mathrm{kWh}\right)$. The total difference in annual carbon emissions based on the scenario was measured.

\subsection{Results and Discussion}

Using Eq. 25.1 it was calculated that the average energy consumption (AEC) by EV according to their brand and model popularity is $19.45 \mathrm{kWh} / 100 \mathrm{~km}$.

Using the Eq. 25.2, it was estimated that the energy required for the EV scenario (ER) per annum would be $86.3 \mathrm{TWh}$ which added the $7 \%$ grid losses, leading to a total of $22 \%$ rise in energy production at the supply phase.

In relation to carbon emissions (Eq. 25.3), the result revealed $49.5 \mathrm{MtCO}_{2} /$ year (Em) are emitted by all CV today. EV does not produce any traffic emissions, which will lead to a $41.4 \%$ reduction in transport $\mathrm{CO}_{2}$ levels per year.

Using Eq. 25.4, we estimated that a total of $8.6 \mathrm{MtCO}_{2} /$ year will need to be generated additionally from the electricity grid for a $100 \%$ transition to EV.

When we compared the current annual total emissions of all sectors using the EV scenario, it was revealed that carbon emissions will drop by about $41 \mathrm{MtCO}_{2}$ or by $11.6 \%$ annually.

\subsection{Discussion}

In this research, it did not cover the detailed life cycle assessment of CV and EV, as the focus of our study was the electricity consumption based on EV transition scenario and their effect on carbon emissions in the UK. The manufacturing of EV produces slightly higher amounts of carbon emissions than the CV. On the other hand, petrol/diesel cars require fuel, which first must be extracted, processed, and transported to gas stations, all of which generated additional carbon emissions. This is subject to change, as there are constant innovations, which would lead to a reduction in carbon emissions in manufacturing processes. Besides, lots of other variations 
would still need to be further explored such as energy use behaviour. For example, CV uses the engine's heat to warm up the interior space, while electric cars required electricity from the battery in order to provide thermal energy for the interior. These variables and associated future technology will have a significant impact on curbing the carbon emission within the transportation sector.

\subsection{Conclusions}

The expansion of electric cars in the UK would lead to an increase in electricity demand, which would result a rise in carbon emissions due to supply and manufacturing. On the other hand, transport emissions would drop significantly resulting in a total reduction of $\mathrm{CO}_{2}$ levels by $12 \%$ per year. IT can be concluded that transition towards EV would gain a positive effect in reducing $\mathrm{Co} 2$ in the longer-term and further reduction can be achieved if energy efficiency increases at supply and manufacturing level.

\section{References}

1. Department for Business, Energy \& Industrial Strategy, 2020. UK Becomes First Major Economy To Pass Net Zero Emissions Law. [online] GOV.UK. https://www.gov.uk/govern ment/news/uk-becomes-first-major-economy-to-pass-net-zero-emissions-law. Accessed 25 May 2020

2. Web.archive.org. 2020. London Borough Of Bexley - Hiram Maxim And Edward Butler. [online]. https://web.archive.org/web/20160215204601, http://www.bexley.gov.uk/art icle/10664/Hiram-Maxim-and-Edward-Butler. Accessed 25 May 2020

3. T. Lewis. Electric Vs. Fuel Cell Vehicles: 'Green' Auto Tech Explained. [online] livescience.com (2020). https://www.livescience.com/49594-electric-fuel-cell-vehicles-explainer. $\mathrm{html}$. Accessed 25 May 2020

4. D. Hiskey, In 1899 Ninety Percent of New York City's Taxi Cabs Were Electric Vehicles. [online] Today I Found Out (2011). https://www.todayifoundout.com/index.php/2011/04/in1899-ninety-percent-of-new-york-citys-taxi-cabs-were-electric-vehicles/. Accessed 11 May 2020

5. UK Government; Department for Transport, 2018. Vehicle Licensing Statistics: Quarter 1 (Jan-Mar) 2018. Department for Transport, UK government, pp. 1-8

6. D. Moss, How do electric cars work?. [online] What Car? (2019). https://www.whatcar.com/ advice/buying/how-do-electric-cars-work/n18091. Accessed 11 May 2020

7. K. Holmberg, A. Erdemir, The impact of tribology on energy use and $\mathrm{CO}_{2}$ emission globally and in combustion engine and electric cars. Tribol. Int. 135, 389-396 (2019)

8. UK Government; Department for Transport, Provisional Road Traffic Estimates Great Britain: October 2018 - September 2019 (Department for Transport, UK Government, 2019), pp. 1-6

9. B. Lane, Electric Vehicle Market Statistics 2020 - How Many Electric Cars In UK \&\#63. [online] Nextgreencar.com (2020). https://www.nextgreencar.com/electric-cars/statis tics/. Accessed 25 May 2020

10. Department for Business, Energy \& Industrial Strategy, 2019. Digest Of UK Energy Statistics (DUKES): Electricity. Digest of UK Energy Statistics (DUKES): annual data. UK Government, pp. 1-105 
11. Statista, UK: Total Electricity Consumption 2002-2019 | Statista. [online] (2020). https:// www.statista.com/statistics/322874/electricity-consumption-from-all-electricitysuppliers-inthe-united-kingdom/. Accessed 20 April 2020

12. GOV.UK, Energy Trends: UK Electricity. [online] (2020). https://www.gov.uk/government/sta tistics/electricity-section-5-energy-trends. Accessed 22 April 2020

13. Parliamentary Office of Science \& Technology, 2011. Carbon Footprint Of Electricity Generation. Houses of Parliament, pp. 1-4

14. Data.gov.uk, Provisional UK Greenhouse Gas Emissions National Statistics - Data.Gov.Uk (2020)

15. UK Government, Electricity Distribution Losses. A consultation document. UK Government, pp. $1-30$ (2003)

Open Access This chapter is licensed under the terms of the Creative Commons Attribution 4.0 International License (http://creativecommons.org/licenses/by/4.0/), which permits use, sharing, adaptation, distribution and reproduction in any medium or format, as long as you give appropriate credit to the original author(s) and the source, provide a link to the Creative Commons license and indicate if changes were made.

The images or other third party material in this chapter are included in the chapter's Creative Commons license, unless indicated otherwise in a credit line to the material. If material is not included in the chapter's Creative Commons license and your intended use is not permitted by statutory regulation or exceeds the permitted use, you will need to obtain permission directly from the copyright holder. 